Article

\title{
Homogeneity of Determinants in the Financial Sector and Investment in EU Countries
}

\author{
Erika Urbankova (D) and David Krizek * (D) \\ Czech University of Life Sciences, Kamýcká 129, 16500 Prague, Czech Republic; urbankovae@pef.czu.cz \\ * Correspondence: krizekd@pef.czu.cz
}

Received: 13 January 2020; Accepted: 7 February 2020; Published: 17 February 2020

check for updates

\begin{abstract}
This paper evaluates the homogeneity of the financial markets in European Union (EU) countries and the impact of determinants of the financial sector in individual EU countries on the investment by economic entities in the given countries. The objective of the paper is to evaluate the homogeneity of financial sectors in EU countries in terms of individual indicators. The paper also evaluates the interdependence between the loan amount (debt and liabilities of the financial sector) on one side and the selected investments on the other. This paper uses the statistical method of correlation analysis to determine the strength and closeness of dependence among indicators, and the multidimensional statistical method of cluster analysis to determine the homogeneity among the individual countries. The results show that, in terms of financial markets, there is still a difference between developed countries in terms of Gross Domestic Product and the rest of the EU Member States. However, in the case of investment activity that is no longer. Partial integration therefore takes place within the EU, in terms of financial markets.
\end{abstract}

Keywords: financial sector; debt; loans; obligations; investment; European Union; correlation and regression analysis; cluster analysis.

JEL Classification: E4; E5; G0; A1

\section{Introduction}

This article deals with the financial sector at the level of individual states of the European Union (EU). The effort of this group is through the coordination of monetary policy to achieve a single aggregate market. These efforts then appear even in the case of the financial market, which is fundamentally influenced by the monetary union, which associates countries paying with the single currency, the euro. The subject of this article is to examine whether this process of unification is completed, that is, whether there is a financial market in the European Union with close and similar monitored indicators. The basic question then is whether financial markets of nation-states united in the European Union achieve homogeneity and the process of transformation of financial markets in the Member States into a single homogenous unit is completed. The article is also extended to examine the amount of loans for investment activity. As the financial markets primarily consists of credit creation and capital markets are not within the European Union dominant, it is therefore possible to verify, on the basis of this, the theoretical assumption that the relationship between these indicators presupposes. Thus, it is possible to confirm the functioning of financial markets within the European Union, and this is also the second research question of this article. It thus brings an up-to-date view of the issue and newly deals with and evaluates the financial market of the European Union from the perspective of individual Member States. Appropriate data will be generated based on theoretical research to help answer the research questions. Selected statistical methods will also help. Conclusions will then be formulated in a separate chapter. We managed to prove the existence of 
persistent differences between the developed EU countries in terms of Gross Domestic Product (GDP) and the rest, southern and eastern EU Member States. Euro- arena thus does not contribute to greater integration in terms of financial markets. The situation is different in terms of investment activity. Here already homogeneous groups within the group are more diversified not only in terms of economic development but also geographical location. Thus, it can be stated that partial integration within the EU is therefore taking place in terms of financial markets. However, it is still not satisfactory.

\section{Literature Review}

The unification of individual national markets into one homogeneous unit is the intention of the European Union at the level of many markets. This article is primarily focused on financial markets that are modified at the level of individual EU Member States historically, legally and economically. A homogeneous financial market can provide significant benefits to many actors. On the one hand, it offers greater stability, combined with greater resistance to external shocks (Bekaert et al. 2014), lower capital costs, incentives for investment, etc. On the other hand, Chambet and Gibson (2008) using a multivariate GARCH $(1,1)$-M return generating model, in turn, suggests that the financial crisis may reduce integration. However, it proves so on the basis of one crisis and it would be necessary to further verify this hypothesis. Another advantage, for example, identifies Azzimonti et al. (2014) and he proves that integrated financial markets give the government the ability to access more debt finance. Kose et al. (2009) then directly states that open financial markets "unleash forces that result in better government and corporate governance" (Kose et al. 2009, p. 4). However, the integration process itself is time-consuming (Bekaert et al. 2011; Arouri et al. 2012) and it is therefore necessary to evaluate the process over time and identify areas where more effort is needed.

J. M. Keynes, in his time, assumed that savings were completely transformed into investments at the ideal interest rate. That is, the unused portion of an individual's disposable income is used for investment and the whole product is thus divided into two parts. The interest rate is the factor that influences an individual's decision about how to deal with their income (Hachem 2011). Of course, other factors may be mentioned, but this article does not deal with the consumer decision-making theory or others.

As interest rates rise, savings will increase and, as a result, investment will rise, as the two components are identical (Keynes 1963; Duan et al. 2014; Guitiérrez and Lozano 2012). Although at present and in practice the situation is somewhat different, the interest rate has not lost its importance in relation to investment. Assuming that central banks retain some form of independence, their decision on the level of interest rates also directly affects the amount of investment that is made in the country. The lower the interest rate, the more consumer and investment activity, supported by cheaper loans, will grow, and the more the product will grow. On this basis, investments were also supported during the economic crisis, as described by Gros (2014), for example, based on the description and comparison of panel data, Gaiotti (2013) then identifies the importance of loans for investment mainly in times of economic downturn. Furthermore, the importance of loans for investment Nishant Dass and Nanda (2015); De Mitri Stefania and Enrico (2010); Campello et al. (2010).

The theoretical view of investments may not fully reflect reality, in that models are created for perfect conditions and do not consider other interactions and economic factors. The main subjects to which investments and their creation are attributable are companies. A profit-maximizing firm seeks to increase its capital, which, as an input factor, contributes to output creation through investment at the required optimum level (Barro and Sala-i-Martin 1995; Gopalan et al. 2011; Ioannidou and Ongena 2010; Dewally and Shao 2014). Investment also brings innovations, and as Kritikos (2014) describes, these are crucial for further economic progress and new opportunities; similarly, Coad and Hölzl (2010).

In the context of investments, the term investment cycle can be used, as their turnover is even more pronounced than in the business cycle itself. This is due to several factors that determine the level of investment activity. The main determinants include the interest rate, the business cycle itself, 
national savings, and foreign direct investment. These factors are followed by other factors that are related to them and which can also improve or worsen the investment cycle position. The demand for investment is linked to the central bank's interest rate by an inverse relationship, and thus the demand for investment increases with falling interest rates. The interest rate is an investment cost. Other factors influencing investment are company expectations and demand for the output of the given company after realizing the investment (Samuelson and Nordhaus 2007; Panetta and Signoretti 2010; Nerlove 1983).

Increasing investment should result in greater national product growth, as it is one of the components of national wealth, as Ponticelli and Alencar (2016) states; Festus (2011) then characterises the relationship in both the short and long term as investment and economic development being significantly linked. Therefore, interest rate changes are used by central banks to maintain monetary stability and achieve targets (Bernanke and Mark 1995).

The business cycle is the second, very important determinant of investment. If the overall product grows, then the economic situation in the national economy is also favourable to investment activity and the investment and business cycle itself are highly interconnected, as shown by research to many companies, for example Campello et al. (2010). Higher household consumption is increasing the demand for goods and services, to which businesses are responding by increasing supply, often through investment, and also with renewal investments. Similarly, for exports.

The favourable situation is also related to the optimistic expectations of market participants, which motivate them to still greater investment activity, which would not be considered under other, less favourable circumstances. However, as Mandishekwa (2014) proves, this relationship does not necessarily hold; similarly, see, for example, Verman and Wilson (2005). However, the article deals with a developing country where investment is directed towards less developed sectors. This paper will analyse developed countries that invest in modern productivity-enhancing technologies. The investment financing and supply of capital (Lemmon and Roberts 2010; Custódio et al. 2013; Kahle and Stulz 2011; Leary 2009) are also an important factor. It is generally assumed that national savings are the primary source. If they are not high enough to meet the financial demand, there are also foreign sources, i.e., foreign direct investment. Their positive effect is confirmed by the boundary approach to cointegration (ARDL) as well as by the others (Duarte et al. 2017). It again holds that the higher the two determinants, the more investment activity increases, and the cycle itself experiences a boom.

Since the collapse of the Bretton Woods system in the early 1970s, there has been a significant development of financial markets, and with it, globalization of the entire world financial system based on deregulated markets. Alongside this, the key issues related to nation states arose, especially in terms of its ability to continue to manage its economic policies, which impact directly or as externalities on financial markets. For example, Cerny (1994), who, after briefly exploring the different approaches to the financial globalization process itself, identifies the limitations of possible policy interventions, has been dealing with this issue in detail, while others report instability directly (Thompson 2017; Lin 2014). However, due to economies of scale and reduced transaction costs, further technological developments are taking place. Despite these findings, the nation states themselves continued to support the integration and globalization of financial markets, in particular (1) granting freedom to market actors through liberalization initiatives; (2) preventing major international financial crises; and (3) choosing not to implement more effective controls on financial movements (Helleiner 1995). However, this is changing as a result of the financial crisis and subsequent economic crisis, which not only nation states but also the European Commission again seeks greater efficiency interventions regulatory and supervisory authorities (Helleiner et al. 2018; Underhill 2015). However, this may run counter to negative externalities or ultimately impact differently on EU Member States with varying effects if Member States' financial markets are not very close. Critical examination of the process of integration of financial markets within the EU is therefore more necessary than ever. We have identified a fundamental lack of professional debate concerning the evaluation of homogeneity of EU 
financial markets and ignoring the potential heterogeneity of financial markets within the EU. This is all the more problematic in case of decline in the economic cycle can then in various homogeneous groups composed of national financial markets affect the impact of policies with different force and effect and is thus necessary to seek further potential for better monitoring and management of highly interconnected economic and financial systems and, thus, may help anticipate and manage future crises (Battiston et al. 2016). However, we cannot study asymmetries and structures, such as Battiston et al. (2016) among homogeneous groups, unless their substance is clear and on the basis of what indicator they are formed. One of our assumptions is that it has a positive effect on the homogeneity of financial markets when a state is a member of a monetary union, i.e., the euro area.

\section{Data and Methods}

Three research questions related to the main objective are identified:

- Are homogeneous financial markets and investment activities in the European Union countries that are members of the EMU the same as those that are not members of the EMU?

- Are the European Union's financial markets and investment activity homogeneous within the Visegrad Group countries?

- Are EU countries different in terms of financial markets and investment activity?

In connection with the partial objective are set two other research questions:

- Does GDP per capita (PPS) depend on the volume of loans to non-financial institutions in the European Union?

- Does GDP per capita (PPS) depend on the volume of investment in the EU countries?

It can be assumed that central banks, when deciding on the level of interest rates, also directly affect the amount of loans and, consequently, the amount of investments that are made in the country. The lower the interest rate (discount rate, Lombard rate), the greater the volume of loans provided and, consequently, the higher the consumption and investment activity supported by cheaper loans. This will also result in an increase in asset prices and a rise in gross value added in sectors of the national economy, and by extension gross domestic product. To examine this influence, several macroeconomic variables have been selected, which are described in Table 1 together with the abbreviations used in the analyses and the units of measure.

Table 1. Description of macroeconomic variables.

\begin{tabular}{cccc}
\hline Area & Abbreviation & Variable & Unit of Measure \\
\hline & Debt_securities_NF & $\begin{array}{c}\text { Private sector debt: debt securities of non-financial } \\
\text { institutions, consolidated }\end{array}$ & in \% GDP \\
\cline { 2 - 4 } & Debt_NF & $\begin{array}{c}\text { Private sector debt: loans to non-financial institutions, } \\
\text { consolidated }\end{array}$ & in \% GDP \\
\cline { 2 - 4 } & Debt_C & Private sector debt: household loans, consolidated & in \% GDP \\
\cline { 2 - 4 } & Credit_flow_securities_NF & $\begin{array}{c}\text { Credit flow in the private sector: debt securities of } \\
\text { non-financial institutions, consolidated }\end{array}$ & in \% GDP \\
\cline { 2 - 4 } & Credit_flows_C & Credit flows in the private sector: loans to & in \% GDP \\
\cline { 2 - 4 } & Liabilities_FI & Liabilities of financial institutions, consolidated & consolidated \\
\cline { 2 - 4 } & Liabilities_CB & Central bank liabilities, consolidated & in \% GDP \\
\hline Total_liabilities & Total financial sector liabilities, consolidated & in \% GDP \\
\hline
\end{tabular}


Table 1. Cont.

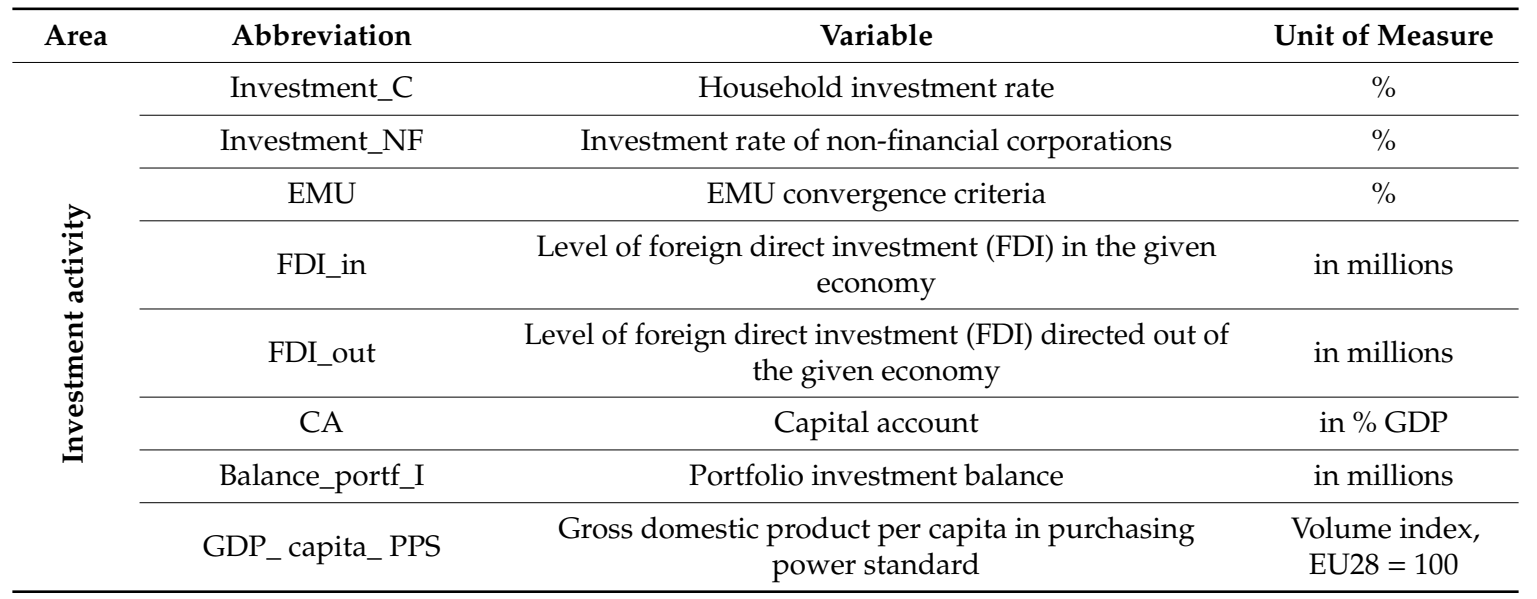

Table 1 brings together several financial sector indicators. Debt securities are transferable financial instruments serving as evidence of debt. Loans are financial assets created when creditors lend capital to borrowers, either directly or through intermediaries. Data are expressed as a percentage of GDP and are presented in a consolidated form, i.e., excluding transactions within the same sector. The definitions of sectors and instruments are based on the European System of Accounts ESA 2010. The indicators are as follows (Eurostat 2019):

- The status of debt securities (Debt_securities_NEF) held by non-financial corporations.

- $\quad$ Loan status (Debt_NF, debt_C) held by the non-financial corporations and households' sectors.

- Net flows of debt securities (Credit_flows_securities_NF) to non-financial corporations.

- Net credit flows (Credit_flows_NF, Credit_flows_C) to non-financial businesses and households.

- The development of the sum of all financial sector liabilities (Total_liabilities), which includes currency and deposits, debt securities, loans, equity and investment fund shares, insurance, pension and standardized guarantee schemes, financial derivatives and employee stock options and other liabilities of financial institutions.

- Developments of all liabilities of financial institutions (Liabilities_FI) include money market funds, collective investment funds, financial intermediaries other than insurance corporations and pension funds, auxiliary financial institutions, captive finance institutions and money lenders, insurance companies, and pension funds.

- Development of all central bank liabilities (Liabilities_CB).

Table 1 also includes several indicators of investment activity of economic entities (Eurostat 2019):

- Gross household investment (Investment_C) is defined as gross fixed capital formation divided by gross disposable income adjusted for changes in net equity of households in pension funds reserves. Household investment mainly consists of purchases and renovation of dwellings.

- The rate of gross investment of non-financial corporations (Investment_NF) is defined as gross fixed capital formation divided by gross value added. This ratio relates the investment of non-financial corporations in fixed assets (buildings, machinery, etc.) to the added value generated during the production process.

- The Maastricht long-term interest rate criterion (EMU) is used as a convergence criterion for the European Monetary Union in the area of long-term interest rates (gross government bond yields on the secondary market with an average residual maturity of around 10 years).

- $\quad$ Foreign direct investment (FDI_in) from the international investment category is carried out by a foreign entity (direct investor) purchasing an entity in the domestic economy for the purpose of earning a profit, while a direct investor controls at least $10 \%$ of the entity's capital. For the 
comparability of economies of different sizes, FDI inward data is expressed as a share of the reporting country's GDP.

- Foreign direct investment (FDI_out) from the international investment category is made by the domestic entity (direct investor) purchasing an entity in a foreign economy for the purpose of making a profit, while the direct investor controls at least $10 \%$ of the foreign entity's capital. For the comparability of economies of different sizes, FDI outward data is expressed as a share of the reporting country's GDP.

- The capital account (CA) includes all transactions related to capital transfers and the acquisition or assignment of unproduced non-financial assets. The capital account together with the current and financial accounts form the balance of payments. It is expressed as a percentage of GDP. Financial flows are referred to as credit items, debit items, and balance. This indicator is based on balance of payments data provided to Eurostat by EU Member States.

- International investment position (Balance_portf_I) is a statistical statement showing at some point the value and composition of: financial assets of residents of the given economy, which are claims on non-residents and gold held as reserve assets; financial liabilities of residents of the economy to non-residents. The difference between the foreign financial assets and the liabilities of a given economy can be positive or negative. The indicator is expressed in millions of national currency units and is based on Eurostat's balance of payments statistics.

- Gross domestic product per capita in purchasing power standard (GDP_capita_PPS) is a measure of economic performance. It represents the added value of all manufactured goods and services. The GDP per capita index expressed in purchasing power standard is in relation to the EU-28 average of 100. If a country-specific index is higher than 100, it means that its GDP per capita is higher than the EU-28 average and vice versa. The figures are given in the purchasing power standard-a common currency which wipes out differences in price levels between countries, allowing a comparison of GDP between countries rather than over time

The paper uses the statistical method of correlation analysis to determine the strength and closeness of dependence among indicators and the multidimensional statistical method of cluster analysis to determine homogeneity among countries. The source of secondary data is Eurostat (2019), which includes data on the investment activity of economic entities and the entire financial sector. The analysis of secondary data is performed first using correlation analysis, and the strength and direction of dependence of selected variables and the influence of the independent variable on the dependent variable are examined. Correlation analysis represents the mutual relationship between two variables and measures the strength and direction of their dependence. It is assumed that both monitored variables are continuous. The correlation coefficient: (a) takes values from $\langle-1 ;+1\rangle$, which indicates a perfect linear relationship (indirect or direct dependence); (b) is independent of the units of the original variables; it is a dimensionless quantity; (c) does not change its value when the order of the variables is changed; (d) is valid only within the range of the data used; $f$ ) does not necessarily prove a functional relationship between the variables when it differs significantly zero. The correlation coefficient in its absolute value and the dependence between variables may be interpreted as follows: (a) 0 to 0.3 shows weak dependence, (b) 0.3 to 0.8 shows medium dependence, (c) 0.8 to 1 shows strong dependence. The mathematical formula for the Pearson correlation coefficient (Artl et al. 2002):

$$
r=\frac{\sum_{i=1}^{n}\left(x_{i}-\bar{x}\right)\left(y_{i}-\bar{y}\right)}{\sqrt{\sum_{i=1}^{n}\left(x_{i}-\bar{x}\right)^{2} \sum_{i=1}^{n}\left(y_{i}-\bar{y}\right)^{2}}}
$$

where $x, y$ are the measured first and second values; $\bar{x}$ is the arithmetic mean of the first measurements; $\bar{y}$ is the arithmetic mean of the second measurements; $n$ is the number of observations. 
When testing the statistical significance of the correlation coefficient, the null hypothesis $\mathrm{H}_{0}$ : $\varrho=0$ on the independence of quantities $X$ and $Y$ against the alternative hypothesis $\mathrm{H}_{1}: \varrho \neq 0$ on the dependence of quantities $X$ and $Y$ is tested. The test criterion is evaluated by comparing the absolute value of the test criterion $|t|$ with a tabulated value of $t_{1-\alpha} / 2(n-2)$. If $|t|>t_{1-\alpha} / 2(n-2)$, the $r_{x y}$ coefficient is statistically significant. If $|t|<t_{1-\alpha} / 2(n-2)$, the $r_{x y}$ coefficient is statistically insignificant.

Regression analysis describes the dependence of a certain quantitative variable on one or more quantitative variables, predetermining which variable is independent (explanatory) and which variable is dependent (explained). The paper uses a simple regression that describes the dependence of the explained variable on only one explanatory variable and the selected function is linear. The linear regression function is mathematically written as follows: $y=\beta_{0}+\beta_{1} x$. The variable $y$ is a dependent variable, the variable $\beta_{0}$ is a constant (the parameter that determines the position of the line), the variable $\beta_{1}$ is the regression coefficient (the parameter that determines the slope of the line), the variable $x$ is the independent variable. Parameter estimation is based on the least squares method. This method approximates one-dimensional data with a straight line that has the smallest sum of squares of the prediction difference. Verification of statistical significance of parameters is evaluated based on the $t$-test and $p$-value of the relevant significance test. The partial $t$-tests on the regression function parameter values test the validity of the explanatory variable in the regression model. The null hypothesis $\mathrm{H}_{0}: \beta_{\mathrm{i}}$ $=0$ is determined and it is tested whether the regression parameter is significantly different from zero.

Rejection or confirmation of the null hypothesis will be based on the $p$-value. If the significance level of alpha (alpha $=0.05$ ) is greater than the stated value of $p$, the null hypothesis will be rejected, in which case the parameter is statistically significant in the model. The coefficient of determination represents the degree of tightness of the linear dependence and multiplied by hundred indicates the percentage of changes in the dependent variable that can be explained by the selected linear regression function, so it can be interpreted as the model's correspondence with data. The whole model can be further evaluated on the basis of $F$-test. The significance of $F$ is thus related to the significance of the model as a whole (the null hypothesis that all regression coefficients except the absolute term is zero is tested). If this value is less than the selected significance level (0.05), then the model is statistically significant (Artl et al. 2002).

In the case of correlation, but also of regression analysis, we observe mutual dependence, but we do not say and we do not aim to determine how causality is managed. However, the point is at least we suggest what the relationship might look like, which we try to show on the basis of regression analysis and say that one phenomenon conditions another phenomenon only with a certain probability and in different intensity, which we do not investigate and are certainly suitable topics for further research. Further, regression examines the relationship between one dependent variable and one or more independent variables, and our goal is to facilitate understanding of that relationship. A number of different values of a second quantity correspond to a certain value of one quantity. This dependence can be characterized by the theoretical course of dependence and possibly its tightness.

Cluster analysis is used to find groups of similar countries; its aim is to examine whether it is possible to identify the differences between the monitored cases on the basis of selected economic factors. Cluster analysis is a multidimensional statistical method that can be used to identify a group of similarly behaving objects and group them into clusters. Objects inside of clusters are the most homogeneous, and objects belonging to different clusters are the most heterogeneous. Common types of cluster techniques include hierarchical clustering and the K-Means method. Hierarchical clustering begins with n clusters, where each observation forms a separate cluster and ends with one cluster that includes all observations. In each step, the two closest observations or observation clusters are merged into one new cluster. The clustering procedure is captured by a special tree graph, or so-called dendrogram, which shows the individual steps of hierarchical clustering, including the distances at which the individual clusters (or observations) were merged. The dendrogram is also used to present the results. The starting point for clustering is to determine the method of expressing the similarity (distance) of individual cases. The squared Euclidean distance was chosen as the distance metric in 
the presented work. This is the standard distance metric used in geometry, which is generalized to multidimensional data. Ward's method, which is based on the creation of clusters with the highest possible internal homogeneity, and is a hierarchical clustering method recommended by many experts, was used for the clustering itself. One of its advantages is that the chaining of clusters does not occur, as it does, for example, in the case of the nearest neighbor and farthest neighbor methods. Ward's method is based on the analysis of variance, and it selects and merges clusters with a minimum sum of squares. For the purposes of this work, hierarchical clustering is only used to determine the number of clusters that have a tendency to form naturally.

Ward's method:

$$
\Delta C=\sum_{i=1}^{G} \sum_{j=1}^{n}\left(x_{g i j}-v_{g j}\right)^{2}-\sum_{i=1}^{A} \sum_{j=1}^{n}\left(x_{a i j}-v_{a j}\right)^{2}-\sum_{i=1}^{B} \sum_{j=1}^{n}\left(x_{b i j}-v_{b j}\right)^{2}
$$

where $x g i j$ is the value of the $i$ th element of cluster G, G is the number of elements of this cluster, $v g j$ is the average value of the $j$ th clustered variable $G$, etc. (Meloun et al. 2012).

What is specific to Ward's method is that it requires the distance of objects to be expressed by the squared Euclidean distance. In the squared Euclidean distance metric:

$$
D_{E}(x, y)=\sum_{i=1}^{n}\left(x_{i}-y_{i}\right)^{2}
$$

where $x$ is the current value of the component (variable) in the matrix, and $y$ represents the number of factors (Meloun et al. 2012).

The paper is methodically proceeded by firstly, based on the available secondary data, a correlation analysis for 21 European Union countries in 2017 is carried out and the direction and strength of dependence of selected relationships between financial sector indicators, investment activity and economic performance are examined. These are: Debt_NF + Investment_NF, Debt_C + Investment_C, Credit_flows_NF + Investment_NF, Credit_flows_C + Investment_C,GDP_capita_PPS + Debt_NF, GDP_capita_PPS + Debt_C,GDP_capita_PPS + Investment_NF, GDP_capita_PPS + Investment_C. Subsequently, the homogeneity of the countries of the European Union is evaluated for financial sectors and investment activity for 19 EU countries in 2017, individually for financial sectors for 28 EU countries in 2017, and for investment activity for 20 EU countries in 2017. The number of countries entering the analyzes depends on the completeness of the secondary data in the given year 2017. If any country lacks the measured value for a particular variable, it is excluded from the analysis because it cannot adequately replace its value.

\section{Results}

\subsection{Correlation Analysis}

The correlation analysis examines the relationship between the observed variables in the European Union, measuring the strength and direction of dependence. Complete data for all indicators are available for 21 European Union countries in 2017: Belgium, the Czech Republic, Denmark, Germany, Estonia, Spain, France, Italy, Cyprus, Latvia, Lithuania, Luxembourg, Hungary, the Netherlands, Austria, Portugal, Slovenia, Slovakia, Finland, Sweden, and the United Kingdom. The variables for the selected relationships were chosen on the basis of theoretical and economic assumptions as well as on the basis of logical consideration of their relationship. Table 2 shows the results of correlation coefficients for all countries under review, which enter the correlation analysis and only 2017 is monitored. Correlation coefficients were tested for their significance and as a result are statistically significant. For the graphical representation of the correlation (Figure 1), two relations are selected that show the highest correlation coefficient, showing the position of the Czech Republic and indicating the outlying countries (data in Appendix A). Correlation coefficients measure the strength of dependence, 
do not determine causality. Simple linear regression can be used to model the relationship between variables, where one dependent variable (plotted on the y-axis) and one independent variable (plotted on the x-axis) are selected. The influence of the independent variable on the dependent variable can be determined based on the given regression relation.

Table 2 shows the values of the correlation coefficient for the selected variables, a deeper shade of green represents the strength of direct correlation, a deeper shade of red represents the strength of indirect correlation A moderately strong direct relationship was found between gross domestic product per capita and the volume of loans to non-financial institutions $(57.1 \%)$, and further between gross domestic product per capita and household investment (46.3\%). On the other hand, weak direct dependence was found between the volume of loans to non-financial institutions and the investment rate of these institutions (19.2\%); the same applies to the household credit flow and their investment rate $(18.7 \%)$. Very weak direct dependence was found between the gross domestic product per capita ratio and the investment rate of non-financial institutions $(0.5 \%)$. In relation to credit flows of non-financial institutions and the level of their investment, very weak indirect dependence was found $(-1.7 \%)$.

Table 2. Correlation coefficients for selected relationships.

\begin{tabular}{cccc}
\hline The Observed Relationship & Indicator 1 & Indicator 2 & Result \\
\hline Relationship 1 & Debt_NF & Investment_NF & 0.192943 \\
\hline Relationship 2 & Debt_C & Investment_C & 0.351116 \\
\hline Relationship 3 & Credit_flows_NF & Investment_NF & -0.01687 \\
\hline Relationship 4 & Credit_flows_C & Investment_C & 0.187758 \\
\hline Relationship 5 & GDP_capita_PPS & Debt_NF & 0.571182 \\
\hline Relationship 6 & GDP_capita_PPS & Debt_C & 0.370495 \\
\hline Relationship 7 & GDP_capita_PPS & Investment_NF & 0.005208 \\
\hline Relationship 8 & GDP_capita_PPS & Investment_C & 0.462431 \\
\hline
\end{tabular}

To illustrate the paired relationships in point graphs, two relationships were selected that show the strongest dependence between the traits (Figure 1). Relationship 5 is shown in the graph on the left, where gross domestic product per capita in purchasing power standard is chosen as a dependent variable and the volume of loans of non-financial institutions is chosen as an independent variable. The simple linear regression equation has the form:

$$
\text { GDP_capita_PPS }=0.4716 \times \text { Debt_NF }+68.393
$$

Based on the significance $t$-tests and $p$-value, the absolute term and the Debt_NF variable are statistically significant in the model. The interpretation of the equation is as follows: If Debt_NF increases by one unit, the GDP_capita_PPS volume index increases by 0.47 .

Medium-strength direct dependence of the monitored indicators in the European Union in 2017 is clearly shown in the point chart, and the regression coefficient indicates that the linear trend explains this relationship at 33\%. High values are reported by Luxembourg (volume index of gross domestic product per capita is well above the EU28 average at 253, and at the same time the non-financial lending volume is $200.7 \%$ of GDP), while Cyprus has a low volume index of gross domestic product per capita (85) and a high volume of loans to non-financial institutions (208.3\% of GDP) and the Czech Republic has a low volume index of gross domestic product per capita (89) and a low volume of loans to non-financial institutions (31.3\% of GDP). Relationship 8 is shown in the right-hand point graph, where the volume index of gross domestic product per capita in purchasing power standard is chosen as a dependent variable and the household investment rate is selected as an independent variable. The simple linear regression equation has the form:

$$
\text { GDP_capita_PPS }=9.2465 \times \text { Investement_C }+30.471
$$


Based on the significance $t$-tests and $p$-value, the absolute term and Investement_C are statistically significant in the model. The interpretation of the equation is as follows: If Investement_C increases by one unit, the GDP_capita_PPS volume index will increase by 9.24.

It is evident from the point chart that within the European Union in 2017, weak to medium direct dependence of the monitored indicators is shown. Again, it is Luxembourg which shows high values of both monitored indicators (the volume index of the gross domestic product per capita is 253, while the household investment rate is $10 \%$ ). The Czech Republic has a low volume index of gross domestic product per capita (89) and a higher level of household investment (9\%). Finland has the highest value of household investment (11.32\%), while GDP per capita in PPS values are only slightly above the EU28 average (109).
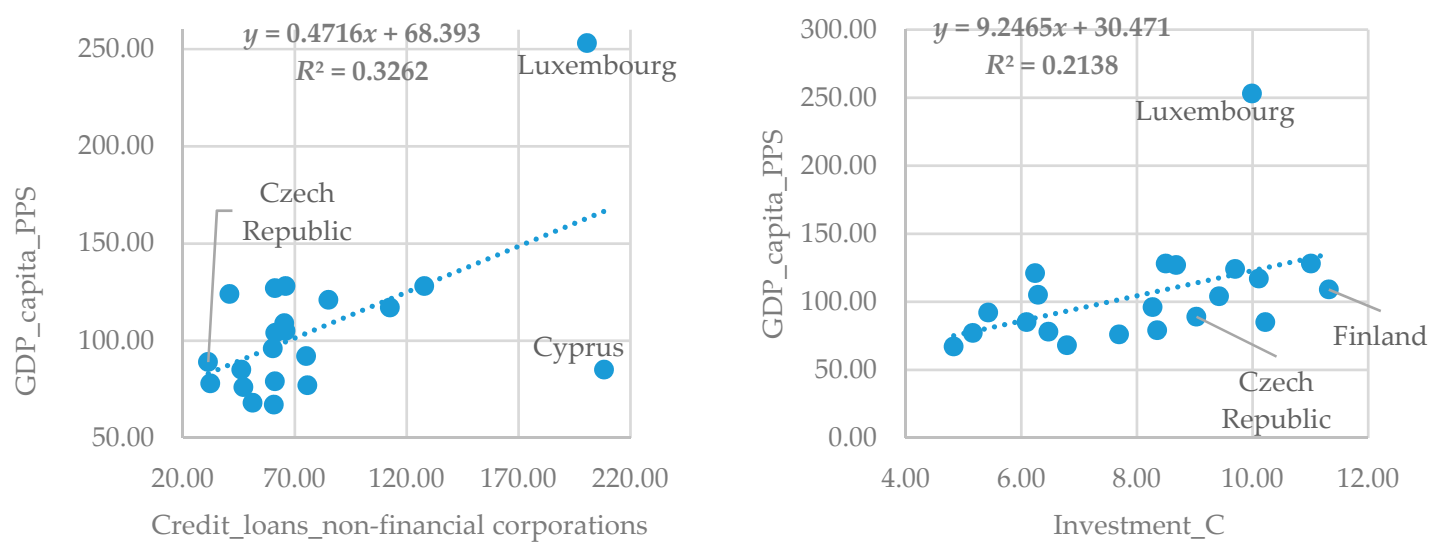

Figure 1. Linear regression of monitored variables in selected EU countries, 2017.

\subsection{Cluster Analysis}

The homogeneity of the European Union countries is first assessed by cluster analysis for financial sectors and investment activity, i.e., all variables declared in Table 2 are entered into the analysis, 2017 is monitored and for all countries for which complete data are available. Furthermore, the cluster analysis is performed individually for financial sectors and for investment activity sector. The number of clusters is determined at the fifth metric distance. So, using cluster analysis, financial market homogeneity and investment activities were examined, together with the performance of the economies of the 28 countries of the European Union in 2017 (only the countries with complete values for all secondary data of the declared indicators; countries with missing data values for indicators are excluded from the analysis): Belgium, Bulgaria, the Czech Republic, Denmark, Germany, Estonia, Ireland, Greece, Spain, France, Croatia, Italy, Cyprus, Latvia, Lithuania, Luxembourg, Hungary, Malta, Netherlands, Austria, Poland, Portugal, Romania, Slovenia, Slovakia, Finland, Sweden, and the United Kingdom. Secondary data are standardized using the z-score method prior to entering them into cluster analysis; because they are in different units of measurement, it is necessary to convert them into dimensionless quantities. All declared variables from the financial market and from the area of investment activity (as listed in Table 1) are used. For clustering, Ward's method using square Euclidean distances was chosen.

The first clustering took place for 19 EU countries for the year 2017 for all declared variables from the financial sector and also from the field of investment activity. Figure 2 shows the dendrogram in which the countries of the European Union form clusters, i.e., homogeneous units; countries in the clusters are most similar within the given indicators. Conversely, countries in other clusters are heterogeneous. The graph is divided at the fifth Euclidean distance and thus three basic clusters are formed (six homogeneous clusters could be created by dividing at the third Euclidean distance).

The representation of the clusters is as follows:

- Cluster 1: Germany, Finland, France, the Netherlands, the United Kingdom, Belgium, Austria, Denmark and Sweden; 
- Cluster 2: Latvia, Lithuania, Italy, Slovenia, the Czech Republic, Spain, Portugal, Cyprus, Hungary;

- Cluster 3: Luxembourg.

The second clustering took place for 27 EU countries for the year 2017 and only for declared variables from the area of the financial sector. Figure 3 shows the dendrogram in which the countries of the European Union form clusters, i.e., homogeneous units; the countries in the clusters are the most similar within the given indicators. Conversely, countries in other clusters are heterogeneous. The graph is divided at the fifth metric distance and three basic clusters are formed.

The representation of the clusters is as follows:

- Cluster 1: Greece, Spain, Malta, the Czech Republic, Lithuania, Italy, Estonia, Poland, Germany, Austria, Romania, Slovenia, Latvia, Hungary, Croatia, Bulgaria;

- Cluster 2: Ireland, Cyprus, Finland, the United Kingdom, France, the Netherlands, Portugal, Belgium, Denmark, Sweden;

- Cluster 3: Luxembourg.

The third clustering took place for 20 EU countries for the year 2017 and only for declared variables in the area of investment activity. Figure 4 shows the dendrogram in which the countries of the European Union form clusters, i.e., homogeneous units; the countries in the clusters are the most similar within the given indicators. Conversely, countries in other clusters are heterogeneous. The graph is divided at the fifth metric distance and three basic clusters are formed.

The representation of the clusters is as follows:

- Cluster 1: Denmark, Austria, Belgium, France, Spain, Sweden, the Czech Republic, Slovakia and Cyprus

- Cluster 2: Latvia, Lithuania and Portugal;

- Cluster 3: Germany, Finland, the Netherlands, Italy, the United Kingdom, Slovenia;

- Cluster 4: Hungary;

- Cluster 5: Luxembourg.

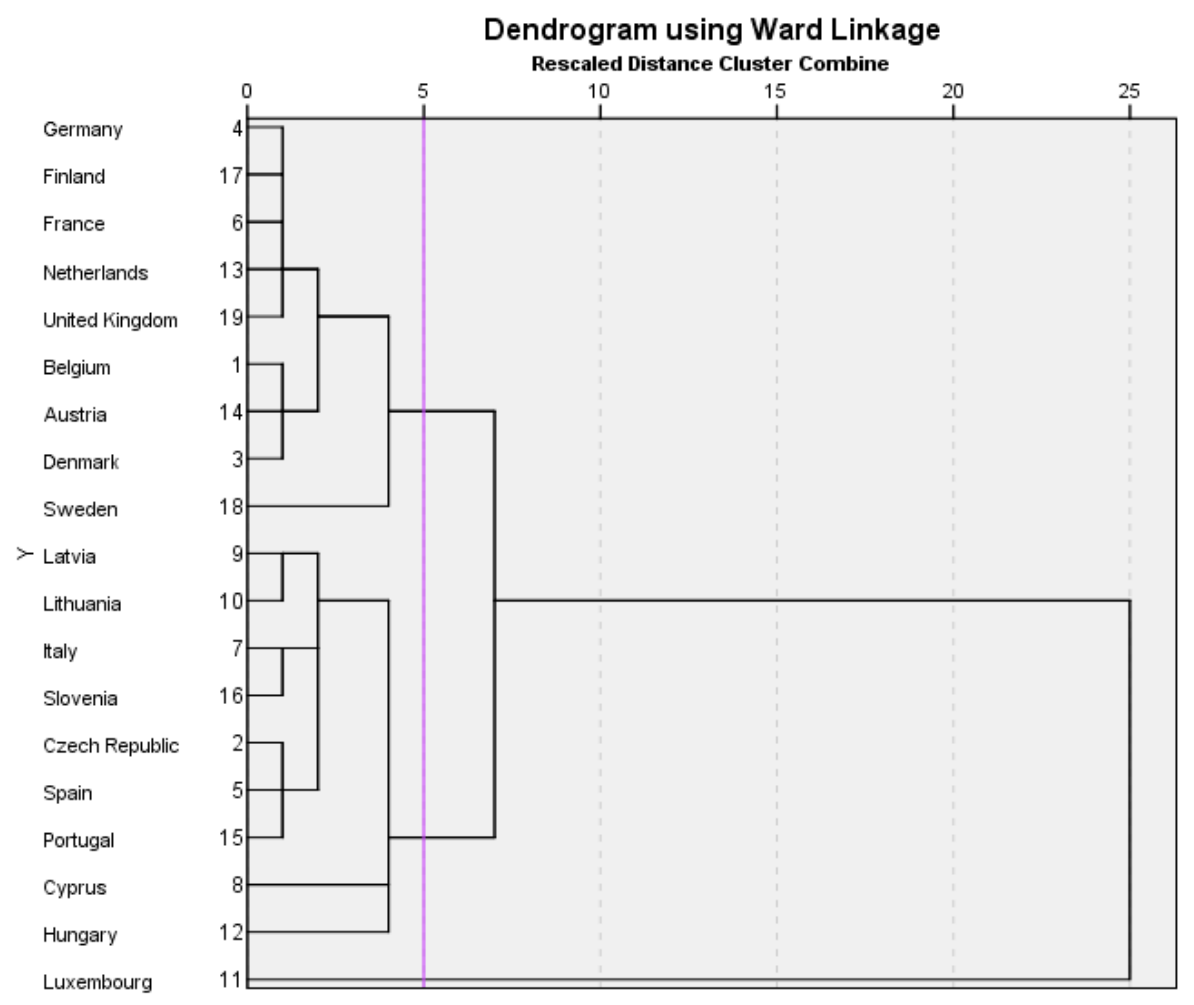

Figure 2. Dendrogram for financial sectors and investment activity, 2017. 


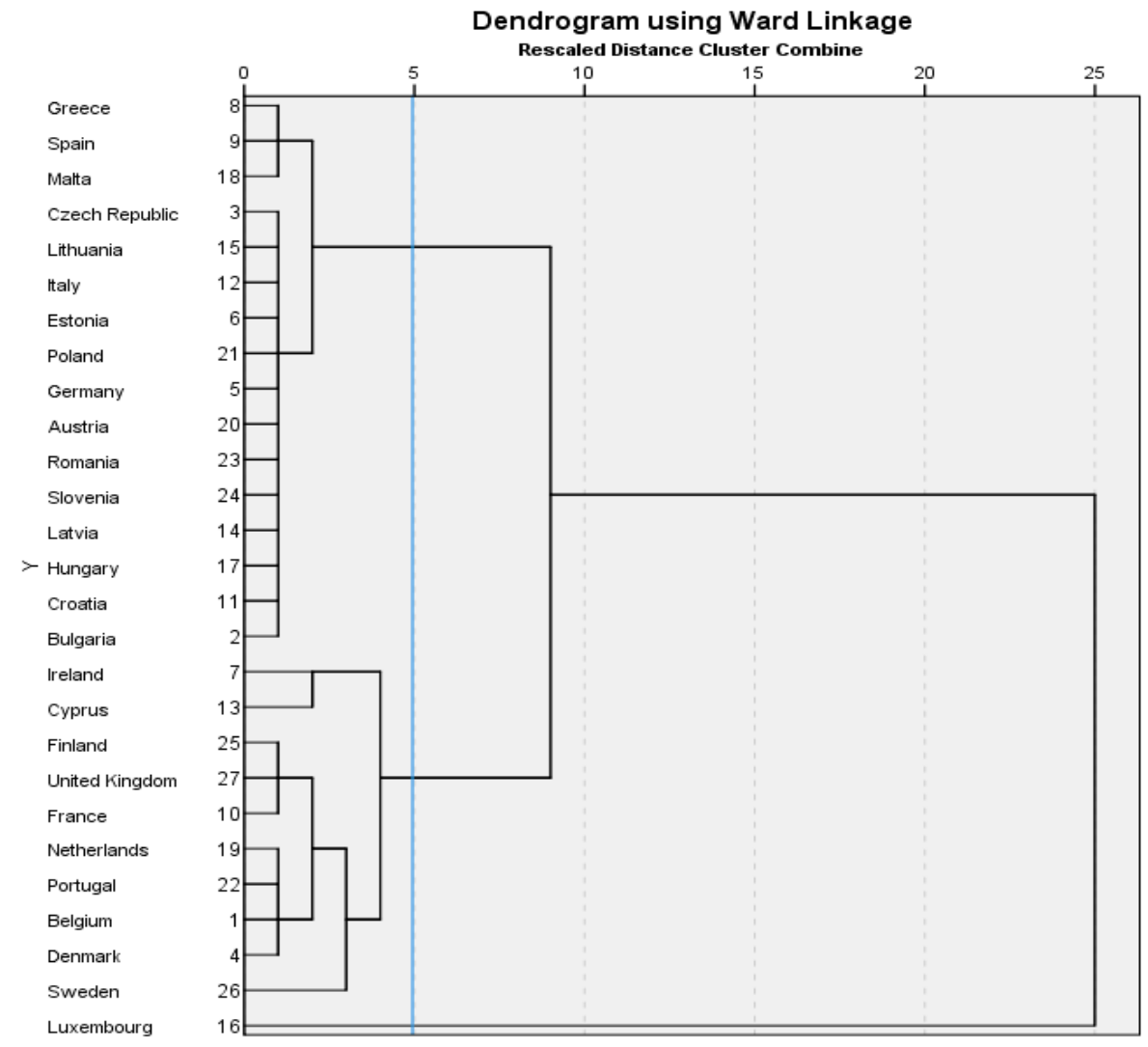

Figure 3. Dendrogram for financial sectors, 2017.

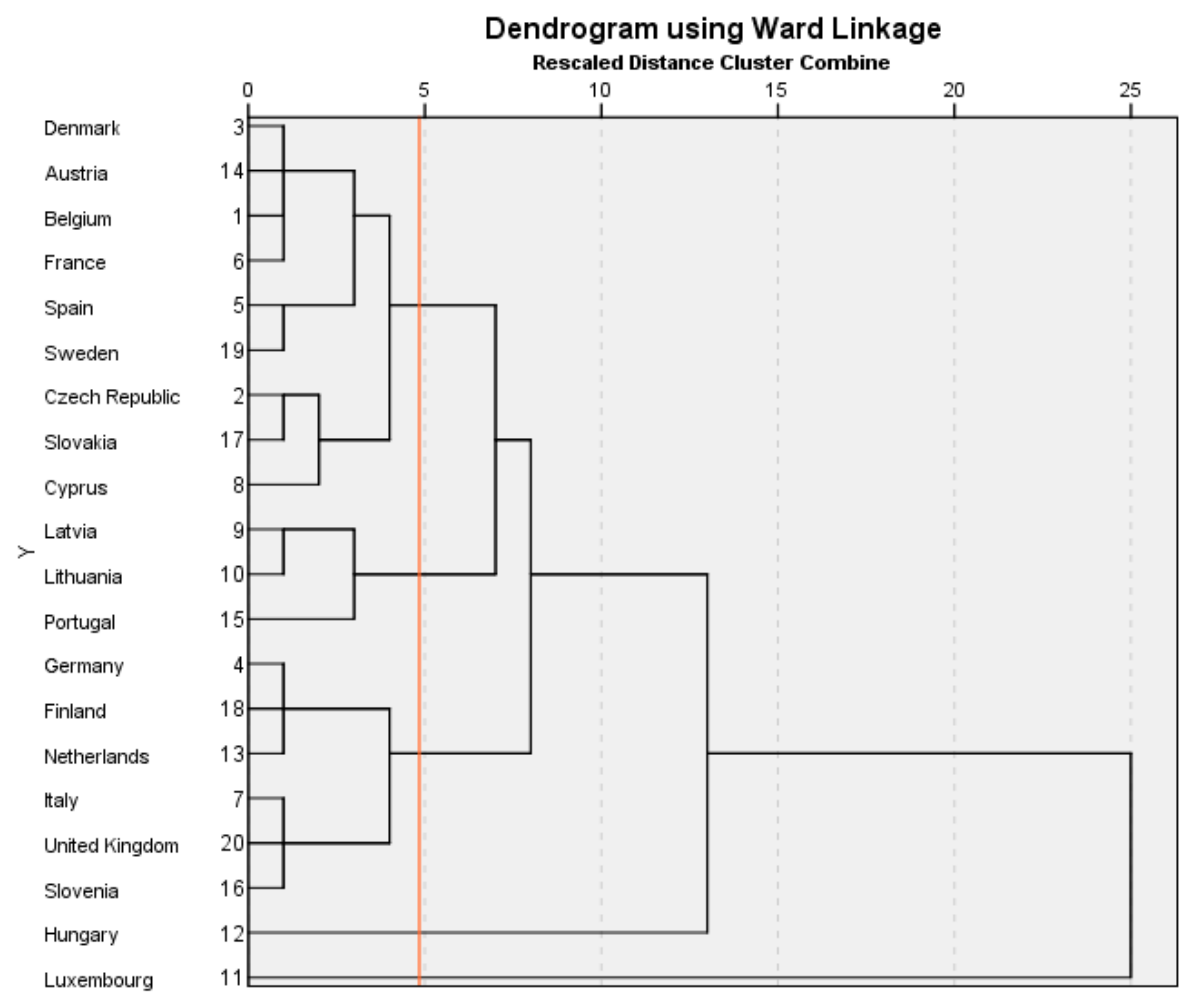

Figure 4. Dendrogram for investment activity, 2017. 


\section{Discussion}

The statistical method of correlation analysis has shown a significant direct relationship between gross domestic product per capita and loans to non-financial institutions. The basic premise of this article is thus proven and the positive relationship between these indicators is verified. The change in gross domestic product is then brought about, among other things, by a change in one of its components, i.e., investments. This relationship is also confirmed by correlation analysis, as the relationship between gross domestic product per capita and the investment activity of non-financial institutions has also been demonstrated. Similarly, Baldwin et al. (2005); Zhang (2001); Al-Fawwaz (2018). Thus, if non-financial institutions draw on loans, GDP growth increases; if they invest, GDP grows again. However, the correlation between the volume of loans and the investment activity of non-financial institutions cannot be confirmed, and this relationship must be rejected, although Jimenez et al. (2012) formulates opposite conclusions. In this case, this is a new finding which needs further investigation. This may be due to the fact that funds used for investment activities are not necessarily borrowed within EU countries. On the basis of the findings in this article, it is therefore necessary to look at and look for other ways to support investment activity. Capital markets may be the answer. However, this does not mean that the relationship with GDP is eliminated, as is confirmed by correlation analysis. It can be assumed that loans are used for consumption, which is again one of the components of GDP and has proven effect; and, as described in Gros (2014), consumption is more significant than investment. Conversely, Akbar et al. (2013) find a relationship between credit supply and business performance and investment. The relationship between GDP and the volume of loans and investments of non-financial institutions is also evident in other European Union countries, and this assumption can be generalized, thus confirming the economic theory predicting this relationship, but also between banks and companies (Braggion and Ongena 2013; Amore et al. 2013; Dwenger et al. 2015). An exceptional deviation is shown by Luxembourg and also Cyprus. Luxembourg is influenced by the high GDP per capita, and in the case of Cyprus, it is the volume of loans to non-financial institutions. Based on the analysis, the relationship between changes in loans and GDP change was also confirmed, as was that between the change in GDP and the investment activity of non-financial institutions. In this way, the basic economic premise was confirmed, and so central banks have the opportunity to influence the economic activity of markets (Lemmon and Roberts 2010; Voutsinas and Werner 2011) and subsequently changes in GDP. These assumptions are confirmed in principle by all EU Member States, with the exception of Luxembourg and, in part, Cyprus. However, both these countries have an atypical economic situation. The article does not, however, confirm the link between household loans and changes in GDP. It is thus possible to contemplate what the cause is, and whether the reaction of households to a change in monetary policy strategy is less elastic than in the case of non-financial institutions. It is also possible to divide further the sector of non-financial institutions, further analyse individual sectors and examine whether the original assumption can be confirmed for all sectors or if there is a disparity in non-financial institutions. On the basis of cluster analysis, when investigating the homogeneity of individual European Union countries within the financial sector and investment activity, three clusters of countries were created which are heterogeneous with each other while the countries within the cluster are homogeneous. The first cluster consists of Western European countries (Germany, Finland, France, the Netherlands, the United Kingdom, Belgium, Austria, Denmark and Sweden); the second cluster consists of Eastern European countries and some southern coastal states (Latvia, Lithuania, Italy, Slovenia, the Czech Republic, Spain, Portugal, Cyprus, Hungary); and the last cluster is Luxembourg, which differs from all countries in terms of foreign direct investment and gross domestic product per capita. Other clustering occurred only within the financial sector. Again, Luxembourg has a stand-alone status within the EU; another cluster is made up of Western European countries, along with the Nordic countries (Ireland, Cyprus, Finland, the United Kingdom, France, the Netherlands, Portugal, Belgium, Denmark, and Sweden) and the third is the Eastern and Southern Europe (Greece, Spain, Malta, the Czech Republic, Lithuania, Italy, Estonia, Poland, Germany, Austria, Romania, Slovenia, Latvia, Hungary, Croatia, Bulgaria). The last clustering took place only for areas of 
investment activity within selected EU countries. In this case, Denmark, Austria, Belgium, France, Spain, Sweden, the Czech Republic, Slovakia and Cyprus are homogeneous. The second cluster consists of Latvia, Lithuania and Portugal; the third cluster, Germany, Finland, Netherlands, Italy, the United Kingdom and Slovenia; the fourth cluster, Hungary; and the last cluster, Luxembourg.

\section{Conclusions}

The aim of this article is to evaluate the homogeneity of the financial sector in the European Union countries on the basis of selected indicators concerning the performance of the economy, the financial sector and investment activity of aggregate economic entities of the national economy. With regard to the first research question, we managed to identify the asymmetric behavior of financial markets in the European Union on the basis of indicators from the financial sector and also from the field of investment activity and variables from the area of the financial sector. However, these differences are not based on euro area membership, but on the persisting differences in economic development, represented by GDP per capita. Naturally, it follows that the countries associated under the Visegrad Four have homogeneous financial markets, as shown by the second clustering on the basis of only the declared variables from the area of the financial sector and thus the second research question is answered. Variables in the area of investment activity no longer divide EU countries according to economic development, but homogeneous groups are also diversified from a geographical location, as demonstrated by the third clustering, and this is the conclusion formulated on the third research question Thus, the article not only analyzes the current situation of the convergence of financial markets to the same level in terms of monitored indicators, but it can also serve as a basis for further research and process of homogenization of financial markets through economic policies, i.e., both fiscal and monetary. Both serve as regulators of this market and determine the rules of operation. On the basis of the development of the regulation of the target group of homogeneous countries, similar rules should be adopted, which will serve as a directive for the desired change of the market and conditions should be created that will contribute to the natural development of financial markets due to deregulation. There is a need to further focus on Eastern and Southern European countries in order to speed up the process of integrating the long years of dysfunctional financial markets with Western European countries, again in terms of both fiscal and monetary policy. These conclusions can continue to contribute to a better understanding of the functioning of the financial market in the European Union in terms of possible differences in behavior and responses to identified groups of national financial markets and to contribute to its homogenisation and the creation of an almost single market by establishing the target group of homogeneous states as the ultimate target for the other groups of homogeneous states and they should thus approach it, on the basis of it. Further research should identify key differences between identified groups. Furthermore, differences between the countries themselves in a homogeneous group can be monitored in order to anticipate their reactions to the business cycle or to identify potential threats for the markets analyzed.

Author Contributions: The authors contributed equally to this work. All authors have read and agreed to the published version of the manuscript.

Acknowledgments: The paper was prepared with the support of the Czech University of Life Sciences Prague (Project IGA PEF No. 20181019).

Conflicts of Interest: The authors declare no conflicts of interest. 


\section{Appendix A}

Table A1. Monitored variables in selected EU countries, 2017.

\begin{tabular}{cccccccc}
\hline Country & $\begin{array}{c}\text { Debt_NF, } \\
\text { \% in GDP }\end{array}$ & $\begin{array}{c}\text { Investment_C, } \\
\%\end{array}$ & $\begin{array}{c}\text { GDP_capita_PPS, } \\
\text { volume index } \\
\text { EU28 }=\mathbf{1 0 0}\end{array}$ & Country & $\begin{array}{c}\text { Debt_NF, } \\
\% \text { in GDP }\end{array}$ & $\begin{array}{c}\text { Investment_C, } \\
\%\end{array}$ & $\begin{array}{c}\text { GDP_capita_PPS, } \\
\text { volume index } \\
\text { EU28 }=\mathbf{1 0 0}\end{array}$ \\
\hline Belgium & 112.60 & 10.11 & 117.00 & Luxembourg & 200.70 & 9.99 & 253.00 \\
\hline $\begin{array}{c}\text { Czech } \\
\text { Republic }\end{array}$ & 31.30 & 9.03 & 89.00 & Hungary & 51.20 & 6.79 & 68.00 \\
\hline Denmark & 65.90 & 8.50 & 128.00 & Netherlands & 128.00 & 11.01 & 128.00 \\
\hline Germany & 40.90 & 9.70 & 124.00 & Austria & 61.20 & 8.68 & 127.00 \\
\hline Estonia & 61.20 & 8.35 & 79.00 & Portugal & 75.70 & 5.16 & 77.00 \\
\hline Spain & 75.20 & 5.43 & 92.00 & Slovenia & 46.20 & 6.09 & 85.00 \\
\hline France & 61.40 & 9.42 & 104.00 & Slovakia & 47.10 & 7.69 & 76.00 \\
\hline Italy & 60.30 & 8.27 & 96.00 & Finland & 65.40 & 11.32 & 109.00 \\
\hline Cyprus & 208.30 & 10.22 & 85.00 & Sweden & 85.10 & 6.24 & 121.00 \\
\hline Latvia & 60.70 & 4.83 & 67.00 & $\begin{array}{c}\text { Knited } \\
\text { Kingdom }\end{array}$ & 65.90 & 6.29 & 105.00 \\
\hline Lithuania & 32.30 & 6.47 & 78.00 & & & & \\
\hline
\end{tabular}

\section{References}

Akbar, Saeed, Shafiqur Rehman, and Phillip Ormrod. 2013. The impact of recent financial shocks on the financing and investment policies of UK private firms. International Review of Financial Analysis 26: 59-70. [CrossRef]

Al-Fawwaz, Abdulrahman. 2018. Foreign Direct Investment and Economic Stability: The case of Arab Peninsula. Advances in Social Sciences Research Journal 5: 200-13. [CrossRef]

Amore, Mario Daniele, Cédric Schneider, and Alminas Žaldokas. 2013. Credit supply and corporate innovation. Journal of Financial Economics 109: 835-55. [CrossRef]

Arouri, Mohamed El Hedi, Duc Khuong Nguyen, and Kuntara Pukthuanthong. 2012. An international CAPM for partially integrated markets: theory and empirical evidence. Journal of Banking and Finance 36: $2473-493$. [CrossRef]

Artl, Josef, Markéta Artlová, and Eva Rublíková. 2002. Analýza ekonomických časových řad s přiklady. Praha: Skripta VŠE.

Azzimonti, Marina, Eva de Francisco, and Vincenzo Quadrini. 2014. Financial Globalization, Inequality, and the Rising Public Debt. American Economic Review 104: 2267-302. [CrossRef]

Baldwin, Richard, Henrik Braconier, and Rikard Forshid. 2005. Multinationals, endogenous growth, and technological spillovers: theory and evidence. Review of International Economics 13: 945-63. [CrossRef]

Barro, R. J., and X. Sala-i-Martin. 1995. Economic Growth. Cambridge: McGraw-Kill.

Battiston, Stefano, J. Doyne Farmer, Andreas Flache, Diego Garlaschelli, Andrew G. Haldane, Hans Heesterbeek, Cars Hommes, Carlo Jaeger, Robert May, and Marten Scheffer. 2016. Complexity theory and financial regulation. Science 351: 818-19. [CrossRef]

Bekaert, Geert, Campbell Harvey, Christian Lundblad, and Stephan Siegel. 2011. What segments equity markets? Review of Financial Studies 24: 3847-890. [CrossRef]

Bekaert, Geert, Michael Ehrmann, Marcel Fratzscher, and Arnaud Mehl. 2014. Global crises and equity market contagion. Journal of Finance 69: 2597-649. [CrossRef]

Bernanke, Ben S., and Gertler Mark. 1995. Inside the Black Box: The Credit Channel of Monetary Policy Transmission. Journal of Economic Perspectives, American Economic Association 9: 27-48. [CrossRef]

Braggion, Fabio, and Steven Ongena. 2013. A Century of Firm-Bank Relationships: Did Banking Sector Deregulation Spur Firms to Add Banks and Borrow More? CEPR Discussion Papers. [CrossRef]

Campello, Murillo, John R. Graham, and Campbell Harvey. 2010. The real effects of financial constraints: Evidence from a financial crisis. Journal of Financial Economics 97: 470-87. [CrossRef]

Cerny, Philip G. 1994. The Dynamics of Financial Globalization: Technology, Market Structure, and Policy Response. Policy Sciences 27: 319-42. [CrossRef] 
Chambet, Anthony, and Rajna Gibson. 2008. Financial integration, economic instability and trade structure in emerging markets. Journal of International Money and Finance 27: 654-75. [CrossRef]

Coad, Alexander, and Werner Hölzl. 2010. Firm Growth: Empirical Analysis. WIFO Working Papers 361.

Custódio, Cláudia, Miguel A. Ferreira, and Luís Laureano. 2013. Why are US firms using more short-term debt? Journal of Financial Economics 108: 182-212. [CrossRef]

De Mitri Stefania, Gobbi Giorgio, and Sette Enrico. 2010. Relationship lending in a financial turmoil. Temi di discussione (Economic working papers), Economic Research and International Relations Area. [CrossRef]

Dewally, Michaël, and Yingying Shao. 2014. Liquidity crisis, relationship lending and corporate finance. Journal of Banking Finance 39: 223-39. [CrossRef]

Duan, Qi, Yong Wei, and Zhiping-Chen Ying. 2014. Relationship between the benchmark interest rate and a macroeconomic indicator. Economic Modelling 38: 220-26. [CrossRef]

Duarte, Leandro do Rosário Viana, Yin Kedong, and Li Xuemei. 2017. The Relationship between FDI, Economic Growth and Financial Development in Cabo Verde. International Journal of Economics and Finance 9: 132. [CrossRef]

Dwenger, Nadja, Frank M. Fossen, and Martin Simmler. 2015. From Financial to Real Economic Crisis: Evidence from Individual Firm-Bank Relationships in Germany. Discussion Papers. Berlin: Free University Berlin, School of Business \& Economics.

Eurostat. 2019. Statistics. Luxembourg: Eurostat.

Festus, Kandenge. 2011. Public and Private Investment and Economic Growth in Namibia (1970-2005). BOJE: Botswana Journal of Economics 7: 2-15.

Gaiotti, Eugenio. 2013. Credit availability and investment: Lessons from the "great recession". European Economic Review 59: 212-27. [CrossRef]

Gopalan, Radhakrishnan, Gregory F. Udell, and Vijay Yerramilli. 2011. Why Do Firms Form New Banking Relationships? Journal of Financial and Quantitative Analysis 46: 1335-365. [CrossRef]

Gros, Daniel. 2014. Investment as the Key to Recovery in the Euro Area? CEPS Policy Briefs, November 18, 326.

Guitiérrez, Ester, and Sebastián Lozano. 2012. Competing risks analysis of the duration of federal target funds rates. Computers Operations Research 39: 785-91. [CrossRef]

Hachem, Kinda. 2011. Relationship lending and the transmission of monetary policy. Journal of Monetary Economics 58: 590-600. [CrossRef]

Helleiner, Eric. 1995. Explaining the globalization of financial markets: Bringing states back in. Review of International Political Economy 2: 315-41. [CrossRef]

Helleiner, Eric, Stefano Pagliari, and Irene Spagna. 2018. Governing the World's Biggest Market: The Politics of Derivatives Regulation after the 2008 Crisis. Oxford: Oxford University Press.

Ioannidou, Vasso, and Steven Ongena. 2010. "Time for a Change": Loan Conditions and Bank Behavior when Firms Switch Banks. Journal of Finance American Finance Association 65: 1847-877.

Jimenez, Gabriel, Steven Ongena, Jose-Luis Peydro, and Jesus Saurina. 2012. Credit Supply and Monetary Policy: Identifying the Bank Balance-Sheet Channel with Loan Applications. American Economic Review, American Economic Association 102: 2301-326. [CrossRef]

Kahle, Kathleen M., and Rene M. Stulz. 2011. Financial Policies, Investment, and the Financial Crisis: Impaired Credit Channel or Diminished Demand for Capital? Fisher College of Business Working Pape. [CrossRef]

Keynes, John Maynard. 1963. Obecná teorie zaměstnanosti, úroku a peněz. Praha: Nakladatelství ČSAV.

Kose, Ayhan, Eswar Prasad, and Marco Terrones. 2009. Does financial globalization promote risk sharing? Journal of Development Economics 89: 258-70. [CrossRef]

Kritikos, Alexander. 2014. Entrepreneurs and their impact on jobs and economic growth. IZA World of Labor. [CrossRef]

Leary, Mark. 2009. Bank Loan Supply, Lender Choice, and Corporate Capital Structure. Journal of Finance, American Finance Association 64: 1143-85. [CrossRef]

Lemmon, Michael, and Michael R. Roberts. 2010. The Response of Corporate Financing and Investment to Changes in the Supply of Credit. Journal of Financial and Quantitative Analysis 45: 555-87. [CrossRef]

Lin, Tom. 2014. The new financial industry. Alabama Law Review 65: 567-623.

Mandishekwa, Robson. 2014. Causality between Economic Growth and Investment in Zimbabwe. Journal of Economics and Sustainable Development 5: 136. 
Meloun, Milan, Jiří Militký, and Martin Hil. 2012. Statistická analýza vícerozměrných dat v přikladech. Praha: Academia Praha.

Nerlove, Marc. 1983. Expectations, Plans, and Realizations in Theory and Practice. Econometric Society 51: 1251-79. [CrossRef]

Nishant Dass, Jayant R. Kale, and Vikram Nanda. 2015. Trade Credit, Relationship-specific Investment, and Product Market Power. Review of Finance 19: 1867-923. [CrossRef]

Panetta, Fabio, and Federico M. Signoretti. 2010. Credit demand and supply in Italy during the financial crisis. Questioni di Economia e Finanza (Occasional Papers) Economic Research and International Relations Area. [CrossRef]

Ponticelli, Jacopo, and Leonardo S. Alencar. 2016. Court Enforcement, Bank Loans, and Firm Investment: Evidence from a Bankruptcy Reform in Brazil. The Quarterly Journal of Economics 131: 1365-413. [CrossRef]

Samuelson, Paul, and William Nordhaus. 2007. Ekonomie: 18. vydání. Praha: NS Svoboda.

Thompson, Grahame. 2017. Time, trading and algorithms in financial sector stability. New Political Economy 22: 1-11. [CrossRef]

Underhill, Geoffrey. 2015. The emerging post-crisis financial architecture: The path-dependency of ideational adverse selection. The British Journal of Politics and International Relations 17: 461-93. [CrossRef]

Verman, Reetu, and Edgar Wilson. 2005. A multivariate Analysis of Savings, Investment and Growth in India. Economics Working Papers. Wollongong: School of Economics, University of Wollongong.

Voutsinas, Konstantinos, and Richard A. Werner. 2011. Credit supply and corporate capital structure: Evidence from Japan. International Review of Financial Analysis 20: 320-34. [CrossRef]

Zhang, Kevin Honglin. 2001. How does foreign direct investment affect economic growth in China? Economics of Transition 9: 679-93. [CrossRef]

(C) 2020 by the authors. Licensee MDPI, Basel, Switzerland. This article is an open access article distributed under the terms and conditions of the Creative Commons Attribution (CC BY) license (http://creativecommons.org/licenses/by/4.0/). 